\title{
The Mediating Effect of Work Category on the Relationship between Professional Competencies` and Decision Making among Public Relations in Government- Linked Companies
}

\author{
KHAIRUL NIZAM SAMSUDIN \\ ZULHAMRI ABDULLAH \\ MOHD NIZAM OSMAN \\ Universiti Putra Malaysia
}

\begin{abstract}
Organisational success can only be materialized when each stakeholder mutually agrees to benefit each other, thus making the organisation effective. And here is the main role of public relations (PR), were to be the middle person between each stakeholder, by performing their works through the competencies they mastered, to ensure that the decisions made will be valuable to organisation and stakeholders. The objective of this study is to examine the mediating effect of work category on the relationship between professional competencies and decision making among PR practitioners in government-linked companies (GLCs). A survey questionnaire was gathered from 157 PR practitioners and data were analysed through SEM PLS. Results indicated that the dimension of work category did influence the relationship between professional competency and decision making. In essence, the decision-making process of a PR practitioner working in Malaysia's GLCs can be enhanced or improved based on the level of professional competencies. The implication of these findings supported the role of the PR department as part of the important sub-system in organisation and competencies acquired by PR practitioners is the resource that able to maintain the survival of an organisation. In the nutshell, a large-scale study should be undertaken, which incorporate a large group of participants in the future to accommodate the responses from a wide population to increase the accuracy of results.
\end{abstract}

Keywords: Public relations, competencies, decision making, mediating effect, GLCs.

\section{INTRODUCTION}

Ideally, the field of public relation (PR) contributes to the growth and development of businesses at local and international levels, and like many other staffs and managers, PR practitioners gradually need to adapt to new fast-changing environments. Even the patterns of execution of PR roles have been understood as differently practice in different organisations due to different activities involved by PR practitioners (Mukhtar \& Shahzad, 2019). Wu and Taylor (2003) point out that public relations are a growing profession in Malaysia. However, as the global work environment is evolving at a fast pace, the PR practitioners in Malaysia must be equipped with the competencies needed in an internationally competitive economy.

Latest, the report from Critical Skills Monitoring Committee (CSC) for 2016/2017, jointly led by Talent Corporation (TalentCorp) and the Institute of Labour Market Information and Analysis (ILMIA), which was developed under the 11th Malaysia Plan, concluded that public relations managers are listed at the top ten professions, which showed that PR practices are crucial for the Malaysian economy. Most of the researchers and scholars state that modern public relations have shifted from persuasive concepts to concepts based on mediation and negotiations as demonstrated by the PR sector. Now, public relations are seen 
The Mediating Effect of Work Category on the Relationship between Professional Competencies 'and Decision Making among Public Relations in Government-Linked Companies

Khairul Nizam Samsudin, Zulhamri Abdullah \& Mohd Nizam Osman

as practising corporate social responsibility (Lee \& Tao, 2020) which enhances corporate engagement with the community (Abdullah et al., 2017).

\section{LITERATURE REVIEW}

Public relations can be defined as the ability to maintain a favourable image or position towards the consumers or stakeholders. Ideally, the mediating effect is used to elaborate on the relationship between independent and dependent variables (Abdul Adis \& Kim, 2013). In essence, work category is identified as the "mediator" to be used in the study to elaborate on the effects of professional competencies and decision making in respect to public relations among GLCs. Moreover, attaining public relations competency would require professionalism in the management of crucial factors that uphold the image and reputation of a given organisation (Abdullah, 2009; Ramos \& Casado-Molina, 2020). Indeed, nowadays public relations is seen as a strategic organisational function to build the strategic relationship between a company and its stakeholders (Valentini \& Edwards, 2019). It is argued that developing the relationship between societal economic inequality and organisations is vital for value creation (Bapuji et al., 2020). Thus, public relations play a key role to align an organisational strategy and its identity (Ravasi et al., 2020; Abdullah \& Seman, 2018).

The paper seeks to establish a mediation model that explain and identify the effects towards GLCs that underlines professional competency and decision making by incorporating work category as a hypothetical variable. Most of the literate and studies, which have been undertaken to understand the significance or influence of competency, in respect to public relations were mostly centred to benefit particular professions that were deemed as "important." However, such notions are changing as described by Anderson (2013) "every person matters in a company, and there is no such thing as an insignificant position". Adnan (2016) stated, "the practice of public relations is becoming more sophisticated than ever with increasing areas of specializations and functions." Meaning the nature of work category in PR is changing hence decision-making processes and professional competences are bound to "shift" significantly: Coherently since there are minimal literature or studies that have been committed to understanding such relationships.

The paper has identified a gap, which seeks to utilise various work category that exists within PR to "find" more knowledge and inter-relationship that exists and how it influences the relationship between professional competency and decision making within Malaysia's GLCs. This is because most of the studies, which relates to PR competence and decision making provides faint information about how these two variables related to governmentlinked companies (Mukhtar \& Shahzad, 2019).

Moreover, PR in most GLCs has evolved into small specialized units as stated by Bright Network (n.d.) "there are dozens of viewpoints and almost as many types of PR". Such "evolvement" has brought changes in the various PR work category, which is influencing the levels of professional competencies and decision-making processes in Malaysia's corporate structure. This resonates with (Rahim et al., 2019) who suggest that the field of public relations has experienced tremendous changes over the last two decades, where traditional roles have been disintegrated and subdivided into the new and specialized niche.

Given the above-motioned observation, the paper has been able to identify various research gaps, which can be used to guide this study that includes: firstly, analysing the relationships between public relations competency and decision making in GLCs; secondly, 
there are fewer studies, which have specifically utilised work category as a mediating tool to explain the relationships between professional competencies and decision making on PR professions in GLCs.

The Indiana University Bloomington (2005) published a public relations guide, which outlined the importance of PR students to expound their knowledge towards understanding other fields, which may be directly or indirectly related to public relations. Such in-depth knowledge and understanding can improve competency and foster decision-making techniques concerning a public relations practitioner. Most of the GLCs are publicly owned and controlled by the Malaysian government thus, large and complex volumes of data and information is typically processed routinely. However, Ekpe et al. $(2015 ; 2016)$ argued that the importance of entrepreneurial skills in improving GLC is vital to harness technological advancement.

Harris et al. (2016) stated that public relations officers are increasingly being required to process immense information before making decisions on how to ensure sustainability, brand, and image of a given GLC organisation. There is a need to ascertain the effects of public relations competency and decision-making tenets in GLCs primarily because of the underlying macro factors, which have significant influence of the reputations of government-owned companies in Malaysia (Abdullah, 2010; Ahmed et al., 2002). These comments resonate with Komodromos (2017) who suggested that companies that incorporate sound PR competency in facilitating proper decision-making frameworks tend to create a sustainable brand, image, and reputation in the long run. Therefore, this current study attempts to study the effects of competency among public relations officers toward decision-making channels utilised by most of Malaysia's GLCs.

The traditional role of public relations in any organisation has always been to enable the latter to boost and expand its brand (Byrum, 2017). However, the contemporary economic structure has evolved especially due to the advancement of technology; this has facilitated the growth and categorization of the public relations departments. As stressed by Ahmad (2019), PR practitioners must be able to improve their skills in using communication technology, especially social media, as a tool in order to achieve organisational goals. This implies that there is a growing need to for PR practitioners to focus on a particular niche in social media such as a publicist, and PR specialist among others within the public relations (Papasolomou \& Melanthiou, 2012); therefore, such evolution in PR departments can enhance the productivity and efficiency of GLCs. There are minimal literature and studies, which delves to analyse the various work category undertaken by PR professions in GLCs especially in Malaysia. This is primarily because the evolvement and expansion currently taking place in the field of public relations in the twenty-first century are still relatively new. Therefore, this paper intends to employ multiple research simulations and techniques to provide a new perspective on the various work category in the PR profession and their impact on Malaysia's GLCs.

The paper delves to analyse the impact of work category on the relationship between professional competencies' and decision making among public relations officers in most Malaysian GLCs. The study was conducted within Malaysia for many reasons, which include: firstly, Malaysia's GLC is ranked fifth globally, in terms, of economic influence (Knight Frank, 2018); secondly, GLCs comprise of almost a half of the Kuala Lumpur Composite Index; thirdly, PR is among the fastest-growing profession in Malaysia hence need for competency; finally, 
for sampling analysing cost since the researcher resides in Malaysia. The findings of the paper document practical recommendations that would be incorporated to enhance PR competency in various work category when deciding concerning Malaysia's GLCs.

Public relations (PR) can be considered as able to create the strategy and develop the strength to develop and sustain relationships and mutual understanding between GLCs and its public. Edward Bernays defines PR as "a management function which tabulates public attitudes, defines policies, procedures and interests of an organisation followed by executing a program of action to earn public understanding and acceptance" (1945). At its meeting in Mexico in 1978, the world assembly of Public Relations Associations agreed that: "Public relations is the art and science of analyzing trends, predicting their consequences, counselling organisation leaders and implementing planned programmes of action which will serve both the organisations and the public interest" (Theaker \& Yaxley, 2018).

In 1991, the Institute of Public Relations (IPR) in the UK defined Public Relations practice as "the planned and sustained effort to establish and maintain goodwill and understanding between an organisation and its publics." (Orakwue, Hammond \& GyambrahAdaefie, 2006, p. 30). Ideally, public relations play a significant role within a given organisation by facilitating a connection between the company as the organisation and the outsiders, mostly the general public, customers, competitors, and other stakeholders. Occasionally, PR is typically confused with marketing and the importance of public relations is overlooked. However, PR is significant towards enhancing sales and consumer base within a given GCL. Moreover, the primary objective of PR is to inform the public, including your potential customers and business partners (Ang \& Ding, 2006).

Notably, GLCs in Malaysia are companies, which can be public or private where the Malaysian government has controlling interest or shares. This implies just like any other publicly or privately owned entity the corresponding PR ought to have significant benefits irrespective of the controlling interest of the government. Closed to home, PR is a fastgrowing and modern management discipline but has not yet become a 'true' profession like medicine, law and accountancy (Abdullah \& Threadgold, 2008).

According to Sha (2011) competencies are specific attributes or qualities that an individual harbour intrinsically that enables them to perform effectively in given work or employment. Ideally, professional competency for Fuller et al. (2018) implies the specific qualities or characteristics that steer an individual to pursue a given professional with excellence and competence. Particularly, there are various professional competencies that employers or organisations typically seek to identify in a given employee or potential recruit, which may include teamwork, career motivation, commercial awareness, and responsibility, commitment, communication and leadership traits among others (Wikijov, n.d.).

In respect to public relations competencies, it can be observed that there is a paradigm shift from the traditional public relations skills and competencies such as excellent writing and media relations. However, with the increasing evolving nature of businesses, there has been an increased need among GLCs to acquire new PR competencies to meet the needs of the organisation. According to Stuart (2017), there are multiple professional competencies, which defines the attributes of public relations officers working for a given organisation. With regards to the enhancing PR professionalism globally, Gregory and Fawkes (2018) created a global capabilities framework for the practitioners, employers and academicians in public relations and communication management. 
The latter noted that monitoring and evaluation, organisational skills, leadership and management, event planning, interpersonal skills, leadership, teamwork and communication skills form the basis of a PR officer professional competencies (Baninajarian \& Abdullah, 2009). Work category generally justifies the existence or classifications of various types of jobs or professions that exist within a given business environment or a given profession. Notably, there is multiple work category that exists within the public relations department such as editors, advertising and promotions, market research analyst, media editor, and public relations managers among others, these specialised categories as dependant on the needs and operational nature of the company (Abran \& Nguyenkim, 1991).

Past studies have been geared towards understanding the correlation between decision making and professional competencies. The paper intends to impact organisations, learning institutions and government as a whole with new literature that provided ardent information that elaborates on the mediating effect of job or work category in regards to underrating the correlation between professional competency and decisions making among public relations officers or departments. In respect to the learning institutions, these institutions can utilise the findings of this study to create, develop, and enhance the educational framework that would assist in equipping and training of future public relations officers especially in matters decision making and competency within the multiple specializations of public relations. This is because most contemporary scholars, academics, and online bloggers are increasingly demystifying the field of public relations from the perspective that it lacks professional competency and practices that can influence informed decision making for organisations or any other business entity (Ang \& Ding, 2006).

Moreover, this will enhance professional competency among public relations officers in Malaysia hence improving decision-making processes. Furthermore, the government of Malaysia plays a crucial role in influencing general operations and functionality of GLCs within Malaysia.

Therefore, the objective of this paper is to examine the mediating role of work category concerning the relationship between professional competencies and decision making within public relations in GLCs across Malaysia. In exploring the mediation of work category, this paper fosters the understanding among people working in public relations by enabling the latter to appreciate the professional values and skills that attributes to PR in respect to decision making.

\section{Population and Sample Selection}

\section{METHODOLOGY}

The population of study are the public relations officers working in the Malaysian GLCs while the sample comprises of the selection of public relations professionals working in GLC companies, which have been listed in Bursa Malaysia. Khazanah Nasional Berhad reported 22 companies as public listed companies, as stated in The Khazanah Report 2015. The majority, which is 12 companies have been listed in the Bursa Malaysia which made these companies relevant to be included in this research. Meanwhile, the other 10 companies were located outside Malaysia and were listed in other stock exchanges. Indeed, it is imperative to note that the targeted sample populations are minimal because the organisations involved in this research were the 12 GLCs, which have been listed in Bursa Malaysia. Therefore, 157 
The Mediating Effect of Work Category on the Relationship between Professional Competencies 'and Decision Making among Public Relations in Government-Linked Companies

Khairul Nizam Samsudin, Zulhamri Abdullah \& Mohd Nizam Osman

respondents responded from the sample of 223 PR practitioners were accepted in this study. SPSS and Smart PLS were used to analyse the data.

Development of Hypotheses

Figure 1 illustrates the proposed hypothesis for this study which includes the following: H1: There is a significant correlation between professional competencies and decisions making

H1a: There is a significant correlation between advanced writing skills and decision making

H1b: There is a significant correlation between project management and decision making

H1c: There is a significant correlation between issues handling and decision making H1d: There is a significant correlation between advanced communication skills and decision making

H2: There is a significant correlation between professional competencies and work categories

H2a: There is a significant correlation between advanced writing skills and work categories

$\mathrm{H} 2 \mathrm{~b}$ : There is a significant correlation between program management and work categories

$\mathrm{H} 2 \mathrm{c}$ : There is a significant correlation between issues handling and work categories $\mathrm{H} 2 \mathrm{~d}$ : There is a significant correlation between advanced communication skills and work categories

H3: There is a significant correlation between work category and decision making H3a: There is a significant correlation between strategic planning and decision making

$\mathrm{H} 3 \mathrm{~b}$ : There is a significant correlation between project management and decision making

H3c: There is a significant correlation between internal communication and decision making

$\mathrm{H} 3 \mathrm{~d}$ : There is a significant correlation between community relations and decision making

H4: Work category mediate the positive relationship between professional competencies and decision making

H4a: Work category has a mediating effect on the relationship between advanced writing skills and decision making

H4b: Work category has a mediating effect on the relationship between program management and decision making

H4c: Work category has a mediating effect on the relationship between issues handling and decision making

H4d: Work category has a mediating effect on the relationship between advanced communication skills and decision making 


\section{Conceptualisation}

Based on the literature, the conceptualization of this study is that when PR practitioners have the necessary professional competencies that would enhance their capability to do their work persistently which then able to affect the decision making.

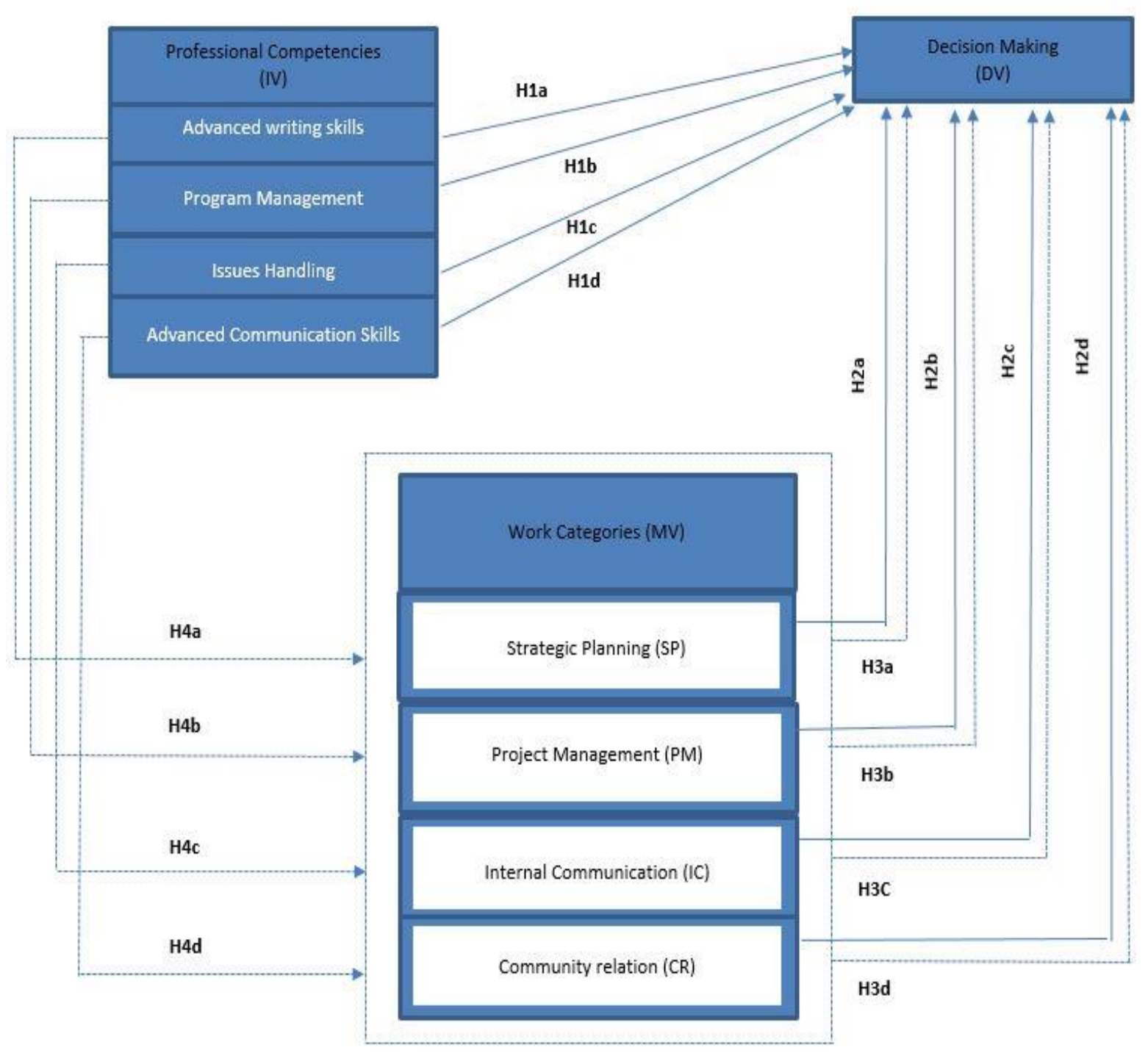

Figure 1: Mediating Effect of Work Category Toward Professional Competencies and Decision Making

\section{Demographic Profile}

RESULTS

The demographic information of the respondents was examined. The results of the study illustrate that $62(39.7 \%)$ of the respondents were male while $94(60.3 \%)$ were observed to be female. In respect to age, 69 (44.2\%), 72 (46.2\%), $12(7.7 \%)$, and $3(1.9 \%)$ of the respondents were observed to be between the ages of 20-29 years, 30-39 years, 40-49 years, and 50-59 years respectively. About job rank, 107 (68.6\%) of the respondents are in executive/officer while 29 (18.6\%) of the respondents were senior executive, and 20 (12.8\%) of the respondents worked as head/manager/senior/manager/director respectively. In regards to education, it can be observed that $3(1.9 \%)$ of the respondents have 
The Mediating Effect of Work Category on the Relationship between Professional Competencies 'and Decision Making among Public Relations in Government- Linked Companies

Khairul Nizam Samsudin, Zulhamri Abdullah \& Mohd Nizam Osman

SPM/STPM/Certificate level of education while 32 (20.5\%), 115 (73.7\%), and 6 (3.8\%) of the respondents have Diploma/ Advanced Diploma, Bachelor's, and Master's degree/ PhD level of education respectively (Table 1 ).

Table 1: Demographic Variable $(\mathrm{n}=157)$

\begin{tabular}{|c|c|c|c|}
\hline No. & Demographic Variable & $\mathbf{N}$ & $\%$ \\
\hline \multirow[t]{3}{*}{1} & Gender & & \\
\hline & Male & 62 & 39.7 \\
\hline & Female & 94 & 60.3 \\
\hline \multirow[t]{5}{*}{2} & Age & & \\
\hline & $20-29$ & 69 & 44.2 \\
\hline & $30-39$ & 72 & 46.2 \\
\hline & $40-49$ & 12 & 7.7 \\
\hline & $50-59$ & 3 & 1.9 \\
\hline \multirow[t]{4}{*}{3} & Job Rank & & \\
\hline & Executive/Officer & 107 & 68.6 \\
\hline & Senior Executive/Officer & 29 & 18.6 \\
\hline & Head/Manager/Senior Manager/Director & 20 & 12.8 \\
\hline \multirow[t]{5}{*}{4} & Education & & \\
\hline & SPM/STPM/Certificate & 3 & 1.9 \\
\hline & Diploma/Advanced diploma & 32 & 20.5 \\
\hline & Bachelor's degree & 115 & 73.7 \\
\hline & Master's degree/PhD & 6 & 3.8 \\
\hline
\end{tabular}

\section{PR Professional Competencies}

The results of mean and standard deviation in the table below relate to the construct of PR professional competencies (PRPC). The findings illustrate that the respondents disagree with the statement PRPCO2 as evident by the below-average mean attained of $2.92 \pm 0.607$. Coherently, the results indicate that the statements PRPC01, PRPC03 and PRPC05 attained a neutral response as illustrated by the means attained of $3.07 \pm 1.119,3.75 \pm 0.649$, and $3.51 \pm 1.075$ respectively. In contrast, it can be observed that most of the respondents agree with the statement PRPC04, which has attained a mean of $4.31 \pm 1.258$, which is above average (Table 2).

Table 2: PR Professional Competencies

\begin{tabular}{lll}
\hline Item & Mean & SD \\
\hline PRPC 2 & 2.92 & 0.607 \\
PRPC 1 & 3.07 & 1.119 \\
PRPC 3 & 3.75 & 0.649 \\
PRPC 4 & 4.31 & 1.258 \\
PRPC 5 & 3.51 & 1.075 \\
\hline
\end{tabular}

\section{Advanced Writing Skills}

The construct of advanced writing skills (AWS) was analysed and examined. The findings represent the responses of the respondents based on the identified construct. The results of the study reveal that the respondents disagree with all the statements AWS1, AWS2, AWS3, 
AWS4 and AWS5 as evident in Table 3, where the means attained of $2.63 \pm 1.320,2.97 \pm 1.496$, $2.47 \pm 1.188,2.81 \pm 1.449$ and $2.67 \pm 1.188$, respectively.

Table 3: Advanced Writing Skills

\begin{tabular}{lll}
\multicolumn{3}{c}{ Table 3: Advanced Writing Skills } \\
\hline Item & Mean & SD \\
\hline AWS 1 & 2.63 & 1.320 \\
AWS 2 & 2.97 & 1.496 \\
AWS 3 & 2.47 & 1.188 \\
AWS 4 & 2.81 & 1.449 \\
AWS 5 & 2.67 & 1.188 \\
\hline
\end{tabular}

\section{Program Management}

The construct of program management (PM) was analysed descriptively. The results of the study reveal that a neutral response was attained for the statement PM1, PM2, PM4, and PM5 respectively as evident by the average mean attained of $3.20 \pm 1.351,3.02 \pm 1.032$, $3.25 \pm 1.408$, and $3.34 \pm 1.356$ respectively. However, most of the respondents disagree with the statement PM3 as evident by the mean attained of $2.36 \pm 1.234$ as depicted in Table 4 .

Table 4: Program Management

\begin{tabular}{lll}
\hline Item & Mean & SD \\
\hline PM 1 & 3.20 & 1.351 \\
PM 2 & 3.02 & 1.032 \\
PM 3 & 2.36 & 1.234 \\
PM 4 & 3.25 & 1.408 \\
PM 5 & 3.34 & 1.356 \\
\hline
\end{tabular}

\section{Issues Handling}

The construct of issues handling was analysed based on the responses of the sampled population. From Table 5 below, it can be observed that the respondents disagree with the statement $\mathrm{IH} 1, \mathrm{IH} 3$, and $\mathrm{IH} 5$, as illustrated by the mean, attained of $2.76 \pm 1.349,2,93 \pm 1.240$, and $2.55 \pm 1.055$ respectively. Moreover, a neutral response was attained for the statement $\mathrm{IH} 2$ and $\mathrm{IH} 4$ as evident by the average mean attained of $3.27 \pm 1.312$ and $3.31 \pm 1.168$, respectively.

Table 5: Issues Handling

\begin{tabular}{llc}
\hline Item & Mean & SD \\
\hline IH 1 & 2.76 & 1.349 \\
IH 2 & 3.27 & 1.312 \\
IH 3 & 2.93 & 1.240 \\
IH 4 & 3.31 & 1.168 \\
IH 5 & 2.55 & 1.055 \\
\hline
\end{tabular}


The Mediating Effect of Work Category on the Relationship between Professional Competencies 'and Decision Making among Public Relations in Government-Linked Companies

Khairul Nizam Samsudin, Zulhamri Abdullah \& Mohd Nizam Osman

\section{Advanced Communication Skills}

The construct of advanced communication skills (ADS) was analysed and the findings were highlighted in Table 6 below. It can be observed that the respondents disagree with the statements ACS1, ACS3, and ACS4 as evident by the mean attained of $2.43 \pm 0.881,2.26 \pm 0.997$, and $2.51 \pm 1.025$ respectively. Besides, a neural response was attained in regards to the statement ACS2 and ACS5 as evident by the mean and SD attained of $3.50 \pm 0.686$ and $3.21 \pm 0.942$ respectively.

Table 6: Advanced Communication Skills

\begin{tabular}{lll}
\hline Item & Mean & SD \\
\hline ACS 1 & 2.43 & 0.88 \\
ACS 2 & 3.50 & 0.69 \\
ACS 3 & 2.26 & 1.00 \\
ACS 4 & 2.51 & 1.03 \\
ACS 5 & 3.21 & 0.94 \\
\hline
\end{tabular}

\section{Work Category}

Work category has been examined and analysed in the context of CR, IN, PM, and SP respectively. In respect to $C R$, it can be observed that a neutral response has been attained for the statement CR1 (3.18 \pm 1.215$),$ CR2 (3.06 \pm 1.222$),$ CR3 (3.02 \pm 1.564$)$, and CR5 (3.12 \pm 1.472$)$. Moreover, it can be observed that respondents disagree with the statement CR4 as evident by the below-average mean of $2.88 \pm 1.391$. About IN, it can be observed that of the statement relating to IN has a neutral response as demonstrated by the average mean and SD of $3.47 \pm 1.00,3.39 \pm 1.462,3.39 \pm 1.173,3.39 \pm 1.278$, and $3.20 \pm 1.282$ respectively. In regards to $\mathrm{PM}$, it can be established that the respondents disagree with the statement PM1 (2.92 \pm 1.081$)$, and the statement PM4 (2.85 \pm 0.620$)$. Coherently, neutral responses were attained in respect to the statements PM2, PM3, and PM5 as evident by the mean attained of $3.39 \pm 1.184,3.22 \pm 0.913$, and $3.14 \pm 1.006$ respectively. In reference $S P$, it can be observed that a neutral response was attained from the statement SP1 $(3.18 \pm 0.876)$ and SP5 (3.42 \pm 1.396$)$. In contrast, it can be further examined that the respondents disagree with the statement SP2, SP3, and SP4 as evident by the mean attained of $2.90 \pm 1.076,2.59 \pm 0.699$, and $2.90 \pm 1.100$, respectively as depicted in Table 7 .

Table 7: Work Category

\begin{tabular}{lcc}
\hline Item & Mean & SD \\
\hline CR 1 & 3.18 & 1.215 \\
CR 2 & 3.06 & 1.222 \\
CR 3 & 3.02 & 1.564 \\
CR 4 & 2.88 & 1.391 \\
CR 5 & 3.12 & 1.472 \\
IN 1 & 3.47 & 1.000 \\
IN 2 & 3.39 & 1.462 \\
IN 3 & 3.39 & 1.173 \\
IN 4 & 3.39 & 1.278 \\
IN 5 & 3.20 & 1.282 \\
\hline
\end{tabular}




\begin{tabular}{lll}
\hline PM 1 & 2.92 & 1.081 \\
PM 2 & 3.39 & 1.184 \\
PM 3 & 3.22 & 0.913 \\
PM 4 & 2.85 & 0.620 \\
PM 5 & 3.14 & 1.006 \\
SP 1 & 3.18 & 0.876 \\
SP 2 & 2.90 & 1.076 \\
SP 3 & 2.59 & 0.699 \\
SP 4 & 2.90 & 1.100 \\
SP 5 & 3.42 & 1.396 \\
\hline
\end{tabular}

\section{Decision Making}

The construct of decision making was analysed. As illustrated in Table 8, it can be observed that a neutral response was attained from statement DM1 as evident by the average mean attained of $3.19 \pm 0.97$. Moreover, the findings of the analysis reveal that most of the respondents agree with statement DM2 as evident by the above-average mean attained of $4.17 \pm 0.98$. In contrast, a neutral response was attained from the respondents in regards to statement DM3, DM4, DM5, and DM6 as evident by the mean attained of $3.12 \pm 1.07$, $3.78 \pm 0.87,3.88 \pm 0.87$, and $3.42 \pm 0.83$ respectively. Lastly, about $\mathrm{DM7}$, it can be observed that the respondents agree as evident by the mean attained of $4.02 \pm 1.28$.

Table 8: Decision Making

\begin{tabular}{lcc}
\hline Item & Mean & SD \\
\hline DM 1 & 3.19 & 0.97 \\
DM 2 & 4.17 & 0.98 \\
DM 3 & 3.12 & 1.07 \\
DM 4 & 3.78 & 0.87 \\
DM 5 & 3.88 & 0.87 \\
DM 6 & 3.42 & 0.83 \\
DM 7 & 4.02 & 1.28 \\
\hline
\end{tabular}

The means of the constructs were examined in Table 9. The results indicate that the construct of strategic planning, advanced writing skills, internal communication, and community relations attained a mean of $3.00 \pm 0.95,3.11 \pm 0.79,3.37 \pm 1.14$, and $3.05 \pm 0.85$ respectively. As shown, all constructs demonstrated moderate levels.

Table 9: Mean Score Each Construct

\begin{tabular}{lccc}
\hline \multicolumn{1}{c}{ Construct } & Mean & SD & Level \\
\hline Mean_Strategic Planning & 3 & 0.95 & Moderate \\
Mean_Advanced writing skills & 3.11 & 0.79 & Moderate \\
Mean_Internal communication & 3.37 & 1.14 & Moderate \\
Mean_Community relations & 3.05 & 0.85 & Moderate \\
\hline
\end{tabular}


The Mediating Effect of Work Category on the Relationship between Professional Competencies 'and Decision Making among Public Relations in Government-Linked Companies

Khairul Nizam Samsudin, Zulhamri Abdullah \& Mohd Nizam Osman

\section{Mediation Analysis}

In terms of internal consistency, all constructs have composite reliability values of more than 0.7. The measurement model also demonstrated satisfactory convergent and discriminant validity by having average variance extracted (AVE) value higher than 0.50 , all manifest variables loaded on their respective latent variable and the square roots of AVE for each construct are greater than its inter-correlation. All dimensions achieved convergent validity, construct reliability and discriminant validity. Meanwhile, Henseler, Ringle and Sarstedt (2015) recommended the values of the Heterotrait-Monotrait Ratio of Correlations (HTMT) must be lower than 0.90 . For the present study, the upper threshold value is 0.888 that complies with the discriminant validity as the value is lower than 0.90 .

Then, after analysation, as depicted in Table 10, it can be established that there is no significant direct effect of work category between advanced communication and decision making $(b=0.0255, t=0.9136$. $p<0.05)$. In contrast, there is a significant direct effect between the relationship of advance writing skills and decision making $(b=0.0806, t=3.5818, p<0.05)$. Issues handling and decision making $(b=0.3232, t=6.5648, p<0.05)$; program management and decision making $(b=0.1527, t=3.6445, p<0.05)$; and $P R$ professional competencies and decision making $(b=0.1204, t=2.8769, p<0.05)$.

Table 10: Direct Effects of Variables

\begin{tabular}{|c|c|c|c|c|c|c|c|}
\hline \multirow[b]{2}{*}{ Hypotheses } & \multirow[b]{2}{*}{ OS } & \multirow[b]{2}{*}{ SM } & \multirow[b]{2}{*}{ SD } & \multirow[b]{2}{*}{$\mathbf{t}$} & \multirow[b]{2}{*}{ P Values } & \multicolumn{2}{|c|}{ Bias Corrected } \\
\hline & & & & & & UB & LB \\
\hline $\begin{array}{l}\text { Advanced communication skills -> Work } \\
\text { categories -> Decision making }\end{array}$ & 0.03 & 0.03 & 0.03 & 0.94 & 0.35 & -0.03 & 0.08 \\
\hline $\begin{array}{l}\text { Advanced writing skills -> Work categories -> } \\
\text { Decision making }\end{array}$ & 0.08 & 0.08 & 0.02 & 3.54 & 0.00 & 0.04 & 0.12 \\
\hline $\begin{array}{l}\text { Issues handling -> Work categories -> Decision } \\
\text { making }\end{array}$ & 0.32 & 0.33 & 0.05 & 6.52 & 0.00 & 0.22 & 0.42 \\
\hline $\begin{array}{l}\text { Managing PR program -> Work categories -> } \\
\text { Decision making }\end{array}$ & 0.15 & 0.15 & 0.04 & 3.66 & 0.00 & 0.07 & 0.23 \\
\hline $\begin{array}{l}\text { PR professional competencies -> Work } \\
\text { categories -> Decision making }\end{array}$ & 0.12 & 0.12 & 0.04 & 2.93 & 0.00 & 0.05 & 0.21 \\
\hline
\end{tabular}

Tables 11 and 12 presented the summary of all the hypotheses. Only 12 hypotheses were accepted and the rest two were rejected.

Table 11: Summary of all descriptive analysis

\begin{tabular}{|c|c|c|}
\hline & Mean score each construct & Results \\
\hline $\mathrm{H} 1 \mathrm{a}$ & Means of the construct is a strategic planning & Moderate \\
\hline $\mathrm{H} 1 \mathrm{~b}$ & Means of the construct is an advanced writing skill & Moderate \\
\hline $\mathrm{H} 1 \mathrm{C}$ & Means of the construct is internal communication & Moderate \\
\hline H1d & Means of the construct is community relations & Moderate \\
\hline
\end{tabular}


Jurnal Komunikasi:

Table 12: Summary of all hypotheses

\begin{tabular}{|c|c|c|}
\hline Item & Hypotheses & Results \\
\hline $\mathrm{H} 2 \mathrm{a}$ & $\begin{array}{l}\text { Advanced writing skill has a significant correlation between work } \\
\text { category }\end{array}$ & Supported \\
\hline $\mathrm{H} 2 \mathrm{~b}$ & $\begin{array}{l}\text { Managing PR program has a significant correlation between work } \\
\text { categories. }\end{array}$ & Supported \\
\hline $\mathrm{H} 2 \mathrm{c}$ & $\begin{array}{l}\text { Issues handling in PR has a significant correlation between work } \\
\text { categories. }\end{array}$ & Supported \\
\hline $\mathrm{H} 2 \mathrm{~d}$ & $\begin{array}{l}\text { Advanced communication skill has no significant correlation } \\
\text { between work categories. }\end{array}$ & Not Supported \\
\hline $\mathrm{H} 3 \mathrm{a}$ & $\begin{array}{l}\text { Strategies planning has a significant correlation between decision } \\
\text { making }\end{array}$ & Supported \\
\hline $\mathrm{H} 3 \mathrm{~b}$ & $\begin{array}{l}\text { Project management has a significant correlation between decision } \\
\text { making }\end{array}$ & Supported \\
\hline $\mathrm{H} 3 \mathrm{c}$ & $\begin{array}{l}\text { Internal communication has a significant correlation between } \\
\text { decision making }\end{array}$ & Supported \\
\hline $\mathrm{H} 3 \mathrm{~d}$ & $\begin{array}{l}\text { Community relations have a significant correlation between decision } \\
\text { making }\end{array}$ & Supported \\
\hline $\mathrm{H} 4 \mathrm{a}$ & $\begin{array}{l}\text { Work categories have no significant mediating effect on the } \\
\text { relationship between advance writing skills and decision making }\end{array}$ & Not-Supported \\
\hline $\mathrm{H} 4 \mathrm{~b}$ & $\begin{array}{l}\text { Work categories have a significant mediating effect on the } \\
\text { relationship between program management and decision making }\end{array}$ & Supported \\
\hline $\mathrm{H} 4 \mathrm{c}$ & $\begin{array}{l}\text { Work categories have a significant mediating effect on the } \\
\text { relationship between issues handling and decision making. }\end{array}$ & Supported \\
\hline $\mathrm{H} 4 \mathrm{~d}$ & $\begin{array}{l}\text { Work categories have a significant mediating effect on the } \\
\text { relationship between advance communication skills and decision } \\
\text { making. }\end{array}$ & Supported \\
\hline
\end{tabular}



Figure 2: Summary of all hypotheses 
The Mediating Effect of Work Category on the Relationship between Professional Competencies 'and Decision Making among Public Relations in Government-Linked Companies

Khairul Nizam Samsudin, Zulhamri Abdullah \& Mohd Nizam Osman

\section{DISCUSSION}

The overall aim of this research is to investigate the research gap identified involving the lack of sufficient research focusing the mediating effect of work category on the relationship between professional competencies and decision making among public relation practitioners of GLCs. Filling this niche can lead to the discovery of new perspectives and ways regarding how to work specialization within public relations can influence the relationship between professional competency and the process of making a decision. Adnan (2016) stated, "the practice of public relations is becoming more sophisticated than ever with increasing areas of specializations and functions". Meaning the nature of work category in PR is changing, hence, decision-making processes and professional competences are bound to shift significantly. Coherently, since, there are minimal pieces of literature or studies that have been committed to understanding such relationships.

The results of the statistical analysis illustrate that various aspect of professional competency such as advanced writing skills, program management, among other do have a significant relationship with decision making. In essence, the decision-making process of public relations officers working in Malaysia's GLCs can be enhanced or improved based on the level of professional competencies. For instance, public relations officers with elevated advanced writing skills are at a significant position to make proper decisions, which may positively influence the performance of their organisations respectively. Proper writing skills forms a central tenet of the term professional competency. Ideally, when individuals possess a broad range of ideas, knowledge, abilities, and skills, this is perceived as the added quality of information suitable for the decision-making process (Van Knippenberg et al., 2004). This demonstrates how professional competency relates to or influence an individual's decisionmaking process. Dozier (1986) argued that "if practitioners are to help organisations adapt to changes in the environment, they must participate in the management decision-making process, not simply implement decisions made by others".

Essentially, professional competencies are generally skills, knowledge and attribute that are specifically valued by the professional associations, organisations and bodies connected to PR professionals' future career. In the context of this study, the findings have identified the necessary professional competencies that fit the context of public relations offers within the GLCs. Black (2003) compiled a list of professional competencies that ought to be demonstrated by PR practitioners, which includes; media relations skills, presentation skills, communication skills, information technology skills, and crisis communication management skills among other skills. Moreover, (Wilcox, 2009; Morris \& Goldsworthy, 2008) have further outlined multiple professional competencies and skills that defines a public relations practitioner. Nonetheless, the observed professional competencies can be summarized or defined into advanced communication skills, advanced writing skills, and issues handling among others. The identified antecedents of professional competencies in this paper have been evaluated from individual respondents who worked in various management levels within the public relations departments in Malaysian GLCs.

The study has employed multiple research techniques and approaches such as direct effect and path coefficient among others. It can be established that the work category has a direct mediating effect between antecedents of professional competencies such as advances writing skills, Issues Handling, Program Managements, PR professional competencies and 
decision making. It is important to note that, writing is among the most wanted job skills in the analysis of job ads classified under term "crisis communication (Labas et al., (2018).

\section{CONCLUSION}

In contrast, there is another aspect of professional competency such as advanced communication skills do not have direct mediating effect in respect to the work category. Overall, it can be established that the work category mediates the relationship between professional competency and decision-making process for most of the public relations officers working in Malaysia's GLCs. It is imperative to note that there are minimal researches of past studies, which can be used by the researcher to make a comparison of cross-reference the findings of this study. Thus, much of the findings in this study lack direct comparison due to the lack of sufficient literature in a similar subject matter. This current study has been able to establish that there is a significant direct effect of work categories between professional competencies dimensions included advanced writing skills, issues handling, program management, and decision making. Those work categories influenced the relationship between professional competencies and decision making which proven that all these dimensions are interdependence as mentioned by the system theory.

The competency in advanced writing skills is found to be the most important skill to be acquired by PR practitioners because, with this skill, PR practitioners can alert and expose the stakeholders and future stakeholder about the progress of the GLCs. Even though, the GLCs in a condition that can be said as 'safe' due to the good performance such as listed in KLSE, however, PR practitioners should always play their role in exposing the GLCs existence in the market and the eye of the stakeholders. The study has utilized a small number of participants, which is perceived to be a small percentage compared to the entire original sample. This means that the results of the findings may not reflect the actual results, which can be adopted outside Malaysia. This is because the population of public relations practitioners working within the GLCs that listed in KLSE may not be clearly defined. Besides, this study focused on a specific group of public relations officers. This can pose a challenge on the implementation of the research findings to be adopted by public relations departments, especially, in the private sectors and SMEs. It is suggested that the future study should focus on PR competency among PR practitioners in SMEs. Therefore, a large-scale study should be undertaken, which incorporate a large group of participants in the future to accommodate the responses from a wide population to increase the accuracy of results. 


\section{BIODATA}

Khairul Nizam Samsudin is a PhD student at the Department of Communication, Faculty of Modern Languages \& Communication, Universiti Putra Malaysia, Malaysia. His current research interests are public relations and corporate communication. Email: khairulnizams@upm.edu.my

Zulhamri Abdullah is an Associate Professor of Corporate Communication at the Department of Communication, Faculty of Modern Languages \& Communication, Universiti Putra Malaysia, Malaysia. His current research interests are strategic communication, reputation management and entrepreneurial communication. Email: zulhamri@upm.edu.my

Mohd Nizam Osman is an Associate Professor at the Department of Communication, Faculty of Modern Languages \& Communication, Universiti Putra Malaysia, Malaysia. His current research interests are New Media Technology and Mass Communication. Email: mo_nizam@upm.edu.my 


\section{REFERENCES}

Abdul Adis, A. A., \& Kim, H. J. (2013). The mediating role of brand recall and attitude towards purchase intention in influencing purchase intention in advergames. Asia Marketing Journal, 15(3), 117-139.

Abdullah, A., Yaacob, M. R., Ismail, M. B., Abdullah, Z., \& Mohd Radyi, S. A. (2017). Corporate engagement with the community: Building relationships through CSR. Journal of Engineering and Applied Sciences, 12(2), 1538-1538.

Abdullah, Z. (2010). Cultural diversity management in Malaysia: A perspective of communication management. In M. Özbilgin \& J. Syed (Eds.), Managing cultural diversity in Asia (pp. 14-38). Edward Elgar Publishing Limited.

Abdullah, Z., \& Seman, R. A. A. (2018). Constructing a unique online corporate identity of Korean companies. Paper presented at AIP Conference Proceedings of the 3rd International Conference on Applied Science and Technology (ICAST'18), 2016, 020004-1-020004-5.

Abdullah, Z., \& Threadgold, T., (2008). Towards the professionalisation of public relations in Malaysia: Perception management and strategy development. Public Relations Review, 34(3), 285-287.

Abdullah, Z. (2009). Beyond corporate image: Projecting international reputation management as a new theoretical approach in a transitional country. International Journal of Economics and Management, 3(1), 170-183.

Abran, A., \& Nguyenkim, H. (1991, October). Analysis of maintenance work categories through measurement. Paper presented at. IEEE Conference on Software Maintenance, Sorrento, Italy. https://www.doi.org/10.1109/ICSM.1991.160315

Adnan, M. H. (2016). Making public relations a true profession in Malaysia by an Act of Parliament: An advocacy. Jurnal Kinabalu, 18. Retrieved from https://jurcon.ums.edu.my/ojums/index.php/ejk/article/view/496, 30/12/2019.

Ahmad, Z. A. (2019). Embracing social media: The change and disruption to public relations practices in Malaysia. Jurnal Komunikasi: Malaysian Journal of Communication, 35(1), 319-337.

Ahmed, A. S., Billings, B. K., Morton, R. M., \& Stanford-Harris, M. (2002). The role of accounting conservatism in mitigating bondholder-shareholder conflicts over dividend policy and in reducing debt costs. The Accounting Review, 77(4), 867-890. https://doi.org/10.2308/accr.2002.77.4.867

Anderson, A. R. (2013). Every person matters in a company, and there is no such thing as an insignificant position. Retrieved from https://www.forbes.com/sites/amyanderson/2013/01/23/every-person-matters-ina-company-and-there-is-no-such-thing-as-an-insignificant-position/\#4b4a1b7679a6, $30 / 12 / 2019$.

Ang, J. S., \& Ding, D. K. (2006). Government ownership and the performance of GovernmentLinked companies: The case of Singapore. Journal of Multinational Financial Management, 16, 64-88.

Baninajarian, N., \& Abdullah, Z. B. (2009). Groups in context: A model of group effectiveness. European Journal of Social Sciences, 8(2), 335-340.

Bapuji, H., Ertug, G., \& Shaw, J. D. (2020). Organisations and societal economic inequality: A review and way forward. Academy of Management Annals, 14(1), 60-91. 
The Mediating Effect of Work Category on the Relationship between Professional Competencies 'and Decision Making among Public Relations in Government-Linked Companies

Khairul Nizam Samsudin, Zulhamri Abdullah \& Mohd Nizam Osman

Black, C. (2003). The PR practitioner's desktop guide. London: Thorogood.

Byrum, K. (2017). Boosting brand reputation and promoting purchase intention through corporate social responsibility communication: A test of source, formats and sentiment effects in social media. Research Journal of the Institute for Public Relations, 3(2), 1-20.

Critical Skills Monitoring Committee (2017). Malaysia's critical occupations list. Retrieved from https://www.talentcorp.com.my, 30/12/2019.

Dozier, D. M. (1986, August 5). The environmental scanning function of public relations practitioners and participation in management decision making. Paper presented at Public Relations Division, Association for Education in Journalism and Mass Communication, Norman Oklahoma.

Ekpe, I., Razak, R. C., Ismail, M., \& Abdullah, Z. (2015). Entrepreneurial skill acquisition and youth's self-employment in Malaysia: How far? Mediterranean Journal of Social Sciences, 6(4), 150-154.

Ekpe, I., Razak, R. C., Ismail, M., \& Abdullah, Z. (2016). Entrepreneurial skill acquisition, psycho-social factors and youth's self-employment in Malaysia. Journal of Entrepreneurship Education, 19(2), 78-88.

Fuller, M., Heijne-Penninga, M., Kamans, E., van Vuuren, M., de Jong, M., \& Wolfensberger, M. (2018). Identifying competence characteristics for excellent communication professionals: A work field perspective. Journal of Communication Management, 22(2), 233-252.

Gregory, A., \& Fawkes, J., (2019). A global capability framework: Reframing public relations for a changing world. Public Relations Review, 45(3), 1-13. https://doi.org/10.1016/j.pubrev.2019.05.002

Harris, E. P., Northcott, D., Elmassri, M. M., \& Huikku, J. (2016). Theorising strategic investment decision- making using strong structuration theory. Accounting, Auditing \& Accountability Journal, 19(7), 1177-1203.

Indiana University Bloomington. (2005). Public relations advising guide: A guide for IUB students preparing for public relations careers. Indiana: Author.

Khazanah Nasional. (2015). Building true value: The Khazanah report 2015. Retrieved from http://www.khazanah.com.my/3012/2019

Knight Frank. (2018). Malaysia retail news. Retrieved from malaysiaretailnews.blogspot.com/2018

Komodromos, M. (2017). Public relations and reputation in small organisations: Creating identity and building reputation for success. Global Business and Economics Review, 19(5), 536-552.

Labaš, D., Pršir, A., \& Puškar, J. (2018, April 13th - 14th). Evolving crisis management: Current jobs and required employee's skills and characteristics analysis. Paper presented at 6 th International OFEL Conference on Governance, Management and Entrepreneurship, New Business Models and Institutional Entrepreneurs: Leading Disruptive Change. Dubrovnik, Croatia, Governance Research and Development Centre (CIRU), Zagreb (pp. 524-582).

Lee, Y., \& Tao, W. (2020). Employees as information influencers of organisation's CSR practices: Theimpacts of employee words on public perceptions of CSR. Public Relations Review, 46(1), 1-13. 
Mukhtar, M., \& Shahzad, K. (2019). Professional roles of public relations in South Asia: A comparative analysis of public and private sectors of Pakistan. South Asian Studies, 33(2), 529-540.

Orakwue, E., Hammond, A. K., \& Gyambrah-Adaefie, N. (2012). Public relations: An alternative communication strategy for achieving competitive advantage in business organisations. Journal of Business and Retail Management Research, 1(1).

Papasolomou, I., \& Melanthiou, Y. (2012). Social media: Marketing public relations' new best friend. Journal of Promotion Management, 18(3), 319-328.

Rahim, S. A. A., Markom, M. N., \& Alsagoff, S. A. (2019). The roles of public relations in an environmental awareness campaign: A case study of SWM Environment Sdn Bhd. Jurnal Kemanusiaan, 17(1-S).

Ravasi, D., Tripsas, M., \& Langley, A. (2020). Exploring the strategy-Identity nexus. Strategic Organisation, 18(1), 5-19.

Ramos, C. M. Q., \& Casado-Molina, A. (2020). Online corporate reputation: A panel data approach and a reputation index proposal applied to the banking sector. Journal of Business Research, 121, 121-130.

Sha, B. L. (2011a). 2010 Practice analysis: Professional competencies and work category in public relations today. Public Relations Review, 37(3), 187-196.

Stuart, H. (2017). Using the competencies for information professionals: By using the competencies to document your expertise, you can chat a path to professional sustainability. Information Outlook, 21(6). Retrieved on 2019, 30 December, from https://www.questia.com/magazine/1G1-529516900/using-the-competencies-forinformation-professionals, 30/12/2019.

Theaker, A., \& Yaxley, H. (2018). The public relations strategic toolkit: An essential guide to successful public relations practice (2nd ed.). London: Routledge.

Van Knippenberg, D., De Dreu, C. K., \& Homan, A. C. (2004). Work group diversity and group performance: An integrative model and research agenda. Journal of Applied Psychology, 89(6), 1008-1022.

Wilcox, D. L., Cameron, G. T., Ault, P. H., \& Agee, W. K. (2009). Public relations: Strategies and tactics (9th ed.). London, UK: Pearson.

WikiJov. (n.d). Key competencies. Retrieved on 2019, 30 December, from https://www.wikijob.co.uk/content/interview-advice/competencies/keycompetencies

Wu, M. Y., \& Taylor, M. (2003). Public relations in Taiwan: Roles, professionalism, and relationship to marketing. Public Relations Review, 29(4), 473-483.

Valentini, C., \& Edwards, L. (2019). Theories in public relations: Reflections and future directions. Public Relations Inquiry, 8(3), 195-200. https://doi.org/10.1177/2046147X19881227 